\begin{tabular}{|c|c|}
\hline 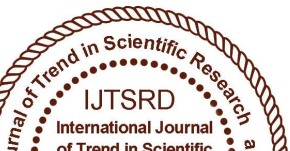 & $\begin{array}{l}\text { International Journal of Trend in Scientific } \\
\text { Research and Development (IJTSRD) }\end{array}$ \\
\hline $\begin{array}{lll} & \\
0\end{array}$ & International Open Access Journal \\
\hline and & ISSN No: $2456-6470$ | www.ijtsrd.com | Volume - 2 | Issue -3 \\
\hline
\end{tabular}

\title{
Characterization of Soil Microbes and Viability Assessment of Liquid Microbial Consortium and Its Effect on the Growth and Yield of Vignaradiata $L$.
}

\author{
Tamilkodi. R, Victoria. J \\ PG and Research Department of Microbiology, \\ S.T.E.T Women's College Mannargudi, Thiruvarur, Tamil Nadu, India
}

\section{ABSTRACT}

The present study was carried out to isolate and identify the bacterial and fungal species from paddy field soil at Vedharaniyam, Nagappatinam District, Tamilnadu, South India. The bacterial and fungal species such as Rhizobium, Azotobactersp and Azospirillumsp, Aspergillussp, Trichodermasp and Penicilliumsp respectively were isolated from paddy field soil by Serial dilution agar plating method. The isolated bacterial and fungal species were prepared as liquid bacterial and fungal consortium and separate broth cultures were also prepared by using specific media. The viability count was checked by using spread plate method as in the broth test. The effectiveness of the growth of VignaradiataL. was tested by using liquid biofertilizer, using different treatments. The seeds were treated with the prepared biofertilizers and sown in 10 pots of equal size. The seedlings of each pot were treated with liquid biofertilizers. The uninoculated pot was denoted as control. Then the morphological parameter such as height of the plant, number of leaves, number of flowers, shoot length, root length, number of roots , inter nodal length, leaf fresh weight, leaf dry weight, root fresh weight, root dry weight, number of seeds, number of root nodules, number of pods and yield were analyzed at different intervals $\left(30^{\text {th }}, 45^{\text {th }}\right.$ and $60^{\text {th }}$ days). Compared to all combined inoculation of liquid biofertilizer T4 and T9 in $60^{\text {th }}$ days showed better response in all the parameters tested.

Keywords: Biofertilizer, Uninoculated, VignaradiataL. Effectiveness, Parameters, Combined

\section{INTRODUCTION}

The mung bean is one of many species recently moved from the genus Phaseolus to Vigna and is still often seen cited as Phaseolusaureus or Phaseolusradiatus. These are all the same plant. Skin colour of mung bean can be classified into dark green, olivine, green black these three kinds, seed skin can be classified as lustrous and unpolished(dark green).The best grade is the one lustrous, big size round shape and easy broken when boiled. Mung Bean is a traditional food source of our Chinese people. Vitamins, calcium, irons and phosphorus ratio higher than crude rice.

Biofertilizers are defined as preparations containing living cells or latent cells of efficient strains of microorganisms that help crop plants in uptake of nutrients by their interactions in the rhizosphere when applied through seed or soil. They accelerate certain microbial processes in the soil which augment the extent of availability of nutrients in a form easily assimilated by plants. Very often microorganisms are not as efficient in natural surroundings as one would expect them to be and therefore, artificially multiplied cultures of efficient selected microorganisms play a vital role in accelerating the microbial processes in soil.

Biofertilizer is one of the important components of integrated nutrient management, as they are cost effective and renewable source of plant nutrients to supplement the chemical fertilizers for sustainable 
agriculture. Several microorganisms and their association with crop plants are being exploited in the production of biofertilizers. They can be grouped in different ways based on their nature and function. The need for the use of biofertilzers has arisen, primarily because of two reasons. The increased usage of chemical fertilizers leads to damage in soil texture and raises other environmental problems. Therefore, the use of biofertilzers is both economical and environment friendly.

\section{Liquid Biofertilizers}

Liquid biofertilizers preparation comprises requirements to preserve organisms and deliver them to the target regions to improve their biological activity or a consortium of microorganisms provided with suitable medium to keep up their viability for certain period which aids in enhancing the biological activity of the target site. Liquid formulation is a budding technology in India and has very specific characteristics and uniqueness in its production methods. Liquid biofertilizers are the microbial preparations containing specific beneficial microorganisms which are capable of fixing or solubilizing or mobilizing plant nutrients by their biological activity.

\section{Bacterial Biofertilizer}

Many rhizospheric bacterial strains possess plant growth-promoting mechanisms. These bacteria can be applied as biofertilizers in agriculture and forestry, enhancing crop yields. Bacterial biofertilizers can improve plant growth through several different mechanisms. Several plant growth-promoting rhizobacteria (PGPR) have been used worldwide for many years as biofertilizers, contributing to increase in crop yields and soil fertility and hence, having the potential to contribute to more sustainable agriculture and forestry. The technologies for the production and application of bacterial inoculum are under constant development and improvement and the bacterialbased biofertilizer market is growing steadily.

\section{Fungal Biofertilizers}

Fungal biofertilizers comprise fungal inoculum either alone or in combination, exerting direct or indirect benefits on plant growth and crop yield through different mechanisms. Fungal biofertilizers, which have been used to improve plant growth by enhancing phosphorus absorption in plants, are phosphate solubilizing microorganisms. The commonly widespread fungi are Penicillium, AspergillusandTrichodermaspecies. There are a number of biofertilizers available in the market. However, applications are based on their ability to supply and mobilize plant nutrients, control plant diseases and promote plant growth and development.

The mung bean or green gram is one of many species recently moved from the genus Phaseolus to Vigna and is still often seen cited as Phaseolusaureus or Phaseolusradiatus. These are all the same plant. Skin colour of mung bean can be classified into dark green, olivine, green black these three kinds, seed skin can be classified as lustrous and unpolished(dark green). The best grade is the one lustrous, big size round shape and easy broken when boiled. Mung Bean is a traditional food source of our Chinese people. Vitamins, calcium, irons and phosphorus ratio higher than crude rice.

\section{MATERIALS AND METHODS}

Soil samples were collected from paddy field at Vedharaniyam, Nagappatinam District, Tamilnadu, South India.Soil samples were taken from each container and subjected to serial dilution followed by pour plate method. Bacterial species were identified by Gram's staining, motility and biochemical tests. Fungal species were identify the by Lacto phenol cotton blue staining.Identified bacterial species such as Rhizobiumsp, Azospirillumsp, Azotobacterspand fungal-species Penicilliumsp, Aspergillusspand Trichoderma sp.

\section{Preparation of Bacterial and Fungal Liquid Biofertilizer}

Prepared bacterial and fungal starter culture byspecific medium. Nutrient broth was used for bacteria and Rose Bengal broth was used for fungi.50ml broth of all three bacteria Rhizobiumsp, Azotobactersp and Azospirillumsp as a liquid biofertilizer was prepared.Three broths were mixed and shakevigorously; this mixture was again incubated for 2 days. Now this broth was called liquid bacterial consortium. $50 \mathrm{ml}$ broth of all three fungi Penicilliumsp, Aspergillusspand Trichodermasp as a liquid bio-fertilizer was prepared. Three broths were mixed and shake vigorously; this mixture was again incubated for 10 days. Now this broth was called liquid fungal consortium. 


\section{Confirmatory test for bacteria}

Confirmatory test were done to identify the presence or absence of specific bacteria in the liquid bacterial consortium.

\section{Confirmatory Test for Rhizobium s}

\section{LactoseAgar Test}

Rhizobium spwas spread out on agar medium containing lactose $(10 \mathrm{~g} \backslash 1)$. The plates were flooded with Benedict's reagent after 4-10 days. The growth of Rhizobiumspin this medium was absent. This indicated the confirmation of Rhizobium sp.

\section{Confirmatory Test for Azospirillumsp}

\section{Pellicle Test}

The active Azospirillumspisolates were inoculated at subsurface level in screw cap tubes containing sterilized semisolid $\mathrm{N}$ - free malate medium (Okonet al., 1977) under aseptic conditions. The tubes were incubated at $30^{\circ} \mathrm{C}$ for a period of one week and observed for growth of Azospirillumspas subsurface pellicle.

\section{Confirmatory Test for Azotobactersp}

\section{Cyst formation}

Azotobactersp have ability to form cysts under adverse conditions. Presence of cyst is as one of the criterion for identification of these isolates. The Azotobacterspisolates were grown N-free agar medium for 7 days. These isolates were stained with a mixture of neutral red and light green SF yellowish, observed under oil immersion microscope.

\section{Mass Production of Liquid Biofertilizer}

Theisolatedstains were grown in respective broth medium in culture tube. After checking the culture for purity and proper growth, the culture was transferred from culture tube to small conical flask containing sterilized liquid medium as starter culture. Later the starter culture was transferred to a large conical flask on a rotary shaker at $150 \mathrm{rpm}$ for 5 days at $28 \pm 2^{\circ} \mathrm{C}$.

\section{Viability Count}

The number of living cells was counted by spread plate method. Doing spread plate by making serial dilutions from $10^{-1}$ to $10^{-7}$ (depend on concentrations) then the replicates of $0.1 \mathrm{ml}$ of broth from $10^{-6}$ and $10^{-}$
${ }^{5}$ was spread over the nutrient agar plates. The plates were incubated in incubator at $37^{\circ} \mathrm{C}$ for 7 days. The number of cells $(\mathrm{ml})$ present in $0.1 \mathrm{ml}$ of broth was determined by multiplying total number of colonies with dilution factor.

No of cells $\backslash \mathrm{ml}=\frac{\text { Mean no of colonies }}{\text { Volume of inoculum }} \times$ dilution factor

\section{Testing the Efficiency of liquid biofertilizer}

\section{Pot Culture}

The efficiency of liquid biofertilizers on the growth and yield of VignaradiataL.was studied using 8 different bacterial and fungal liquid formulations and an uninoculated control for each also maintained.

The bacterial liquid formulation treatments were,

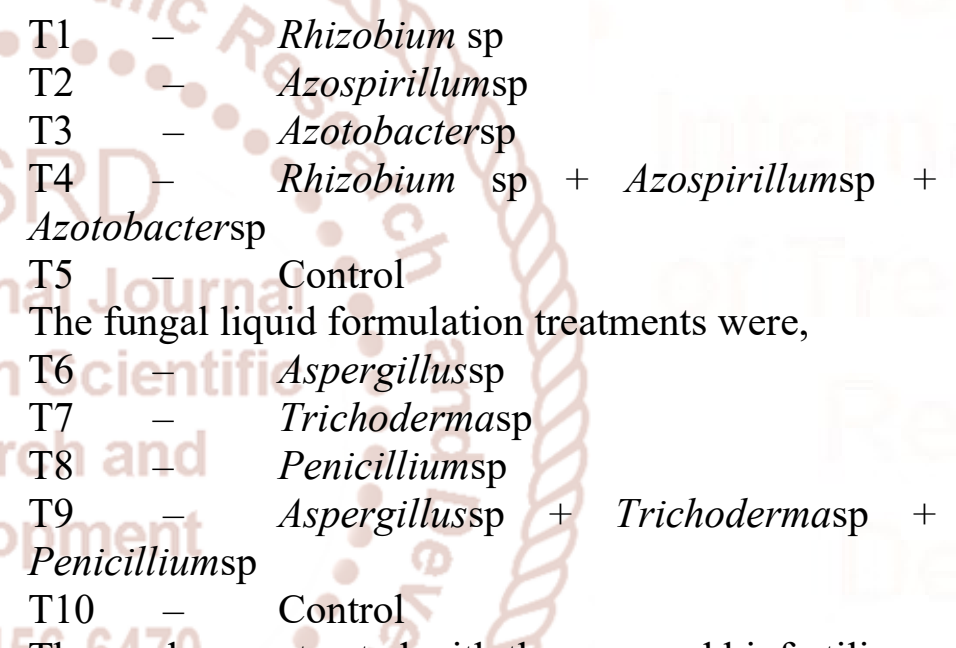

The seeds were treated with the prepared biofertilizers and sown in 10 pots of equal size. The seedlings of each pot were treated with liquid biofertilizers. The uninoculated pot was denoted as control. Liquid biofertilizer was sprayed on plants at 10 days intervals.

The morphometric parameters height of the plant (in $\mathrm{cm})$, number of leaves (per plant), number of flowers (per plant), shoot length (in $\mathrm{cm}$ ), root length (in $\mathrm{cm}$ ), number of roots (per plant), inter nodal length (in $\mathrm{cm}$ ), leaf fresh weight (mglplant), leaf dry weight (mg $\backslash$ plant), root fresh weight (mg $\backslash$ plant), root dry weight (mglplant), number of seeds (in plant), number of root nodules (per plant), number of pods (per plant) and yield (seed in gram) was measured at $30^{\text {th }}, 45^{\text {th }}$ and $60^{\text {th }}$ days of growth.

\section{Statistical Analysis (Gupta, 2004)}

All the experiment was repeated as triplicates. The result obtained in the present study was subjected to 
statistical analysis such as Mean (X) and Standard The standard deviation calculated by the formula, Deviation (SD).

$\operatorname{Mean}(\mathrm{X})=\frac{\sum \mathrm{X}}{N}$

S.D $=\frac{\sqrt{\sum(\mathrm{X}-\bar{X})^{2}}}{\mathrm{n}-1}$

Where,

Mean $(\mathrm{X})$ - Sum of all values of the variable

Where, $\bar{X}$ - Arithmetic mean, X - Number of all values and N- Total number of observation. Find out

$\mathrm{N} \quad-$ Number of observation.

the deviation of each value from the mean $(\mathrm{X}-\bar{X})$ square the deviation and take the total of square

Where, add together all values of variable $\mathrm{X}$ and deviation. Divide the total number of observation. obtain X- X. Divide the total by the number of observation.

Table:1 Morphological and Biochemical Characteristics of Isolated Bacteria

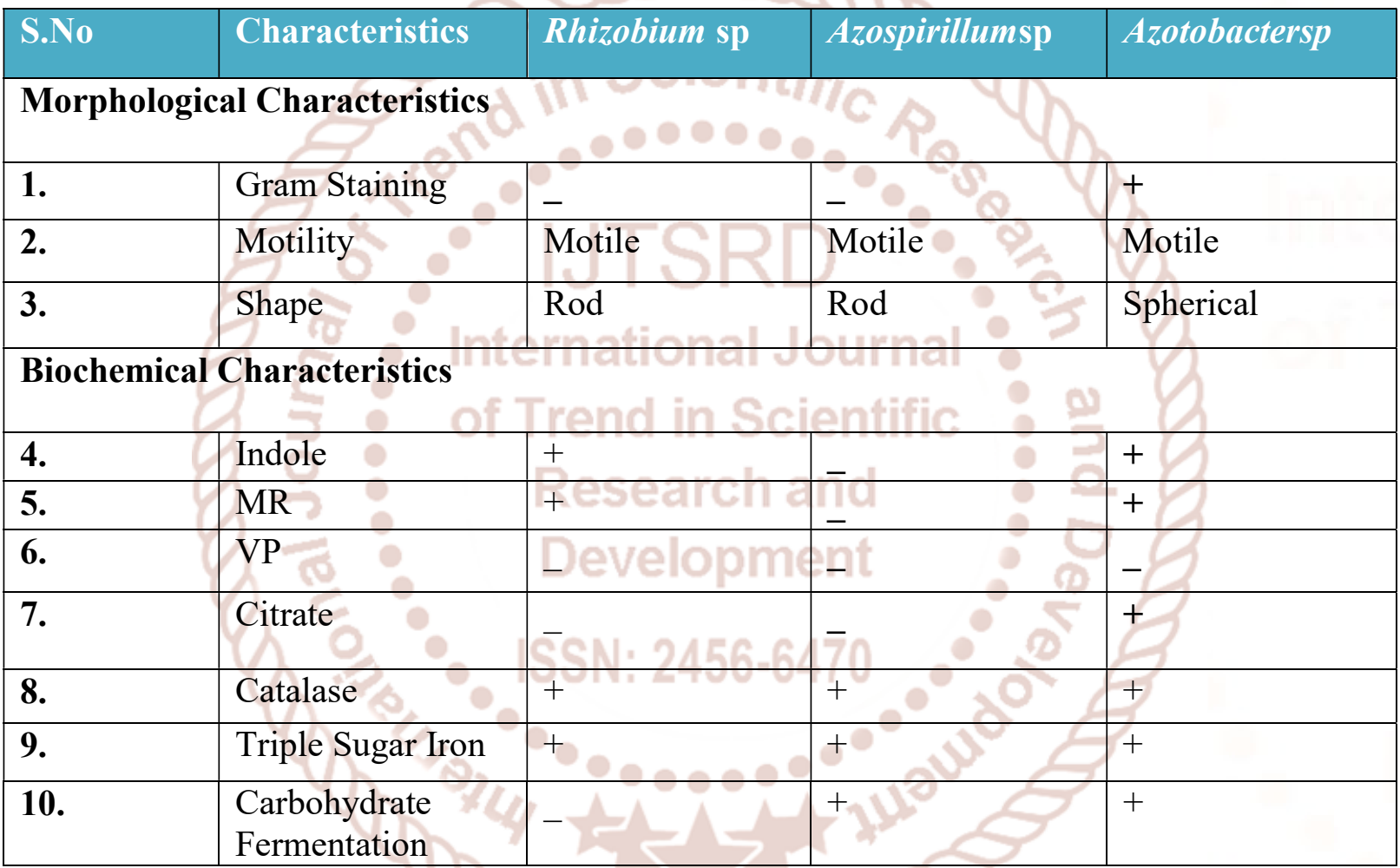

(+) - Positive ,(-) - Negative

Table : 2 Colonial and Morphological Characteristics of IsolatedFungi

\begin{tabular}{|l|l|l|l|}
\hline S. No & Organisms & Colony Morphology & Microscopic Observation \\
\hline 1. & Aspergillussp & Blackish brown & Hyphae septate with conidiospore \\
\hline 2. & Penicilliumsp & $\begin{array}{l}\text { Bluish green to clear } \\
\text { green }\end{array}$ & Aerial hyphae with conidiospore \\
\hline 3. & Trichodermasp & White to pink & Two celled conidia \\
\hline
\end{tabular}


International Journal of Trend in Scientific Research and Development (IJTSRD) ISSN: 2456-6470

Table : 3 Details of Viability Count of bacteria (CFU\ml)

\begin{tabular}{|l|c|c|c|c|}
\hline \multirow{2}{*}{ Species } & Storage time (in months) & \multicolumn{2}{|l|}{} \\
\cline { 2 - 5 } & $\mathbf{0}$ & $\mathbf{1}$ & $2.5 \times 10^{5}$ & $1.8 \times 10^{5}$ \\
\hline Rhizobium sp & $1.9 \times 10^{7}$ & $2.3 \times 10^{6}$ & $3 \times 10^{5}$ & $1.9 \times 10^{5}$ \\
\hline Azospirillumsp & $1.5 \times 10^{6}$ & $1.25 \times 10^{6}$ & & $1.2 \times 10^{5}$ \\
\hline Azotobactersp & $1.7 \times 10^{7}$ & $3 \times 10^{8}$ & $2 \times 10^{6}$ & \\
\hline
\end{tabular}

Table: 4 Details of Viability Count of fungi (CFU $\backslash \mathrm{ml})$

\begin{tabular}{|c|c|c|c|c|}
\hline \multirow[t]{2}{*}{ Species } & \multicolumn{4}{|c|}{ Storage time (in months) } \\
\hline & $\mathbf{0}$ & 1 & 2 & 3 \\
\hline Aspergillussp & $2 \times 10^{7}$ & $.3 \times 10^{6}$ & $3.5 \times 10^{5}$ & $2.8 \times 10^{5}$ \\
\hline Penicilliumsp & $1.2>$ & $2.5 \times 10^{7}$ & $1.9 \times 10^{6}$ & $3.4 \times 10^{5}$ \\
\hline Trichodermasp & 1.5 & $.9 \times 10^{7}$ & $1.7 \times 10^{6}$ & $2.5 \times 10^{5}$ \\
\hline
\end{tabular}

Table: 5 Effect of liquid biofertilizer on morphological parameters of Vignaradiata $\mathrm{L} \cdot\left(30^{\text {th }}\right.$ day)

\begin{tabular}{|c|c|c|c|c|c|c|c|c|c|c|}
\hline \multirow{2}{*}{$\begin{array}{l}\text { Morphological } \\
\text { Parameters }\end{array}$} & \multicolumn{10}{|c|}{ Treatments } \\
\hline & T1 & $\mathbf{T 2}$ & $\mathbf{T 3}$ & TeT4 & 1 T5 & In & T7 & T8 & T9 & T10 \\
\hline $\begin{array}{l}\text { Height of the } \\
\text { plant (in } \mathrm{cm} \text { ) }\end{array}$ & $10 \pm 5.1$ & $9 \pm 3.3$ & $9 \pm 4.5$ & $4 \pm 2.3$ & $8 \pm 2.2$ & $9 \pm 2.2$ & $8 \pm 3.4$ & $9 \pm 2.5$ & $13 \pm 2.5$ & $7 \pm 2.2$ \\
\hline $\begin{array}{l}\text { Inter nodal } \\
\text { length (in } \mathrm{cm})\end{array}$ & $4 \pm 5.1$ & $4 \pm 3.4$ & $4 \pm 4.2$ & $5 \pm 4.2$ & $3 \pm 2.1$ & $4 \pm 2.5$ & $3 \pm 9.2$ & $4 \pm 3.2$ & $5 \pm 2.5$ & $3 \pm 2.3$ \\
\hline $\begin{array}{lr}\begin{array}{l}\text { Number } \\
\text { leaves } \\
\text { plant) }\end{array} & \text { of } \\
\text { (per }\end{array}$ & $9 \pm 2.1$ & $9 \pm 0.2$ & $9 \pm 1.5$ & $9 \pm 4.5$ & $7 \pm 1.2$ & $8 \pm 3.5$ & $8 \pm 1.2$ & $8 \pm 4.5$ & $9 \pm 3.2$ & $7 \pm 2.3$ \\
\hline $\begin{array}{ll}\text { Leaf } & \text { fresh } \\
\text { weight } & \\
\text { (mg\plant) } & \\
\end{array}$ & $8 \pm 7.5$ & $8 \pm 5.7$ & $8 \pm 6.8$ & $8 \pm 9.5$ & $6 \pm 2.5$ & $7 \pm 2.5$ & $7 \pm 1.2$ & $7 \pm 5.9$ & $8 \pm 8.2$ & $6 \pm 5.2$ \\
\hline $\begin{array}{l}\text { Leaf dry weight } \\
\text { (mg\plant) }\end{array}$ & $6 \pm 6.5$ & $6 \pm 4.1$ & $6 \pm 5.5$ & $6 \pm 8.5$ & $5 \pm 1.5$ & $6 \pm 3.2$ & $6 \pm 1.5$ & $6 \pm 2.8$ & $6 \pm 7.2$ & $5 \pm 4.9$ \\
\hline $\begin{array}{l}\text { Number of root } \\
\text { nodules } \\
\text { (per plant) }\end{array}$ & $6 \pm 4.5$ & $5 \pm 2.6$ & $5 \pm 2.8$ & $7 \pm 6.5$ & $4 \pm 1.2$ & $5 \pm 2.5$ & $4 \pm 2.5$ & $5 \pm 2.6$ & $7 \pm 5.7$ & $4 \pm 2.2$ \\
\hline $\begin{array}{l}\text { Shoot length } \\
(\text { in } \mathrm{cm})\end{array}$ & $7 \pm 1.4$ & $4 \pm 9.5$ & $5 \pm 1.5$ & $7 \pm 2.1$ & $3 \pm 1.5$ & $4 \pm 4.2$ & $4 \pm 1.5$ & $4 \pm 9.5$ & $7 \pm 1.4$ & $3 \pm 3.8$ \\
\hline $\begin{array}{l}\text { Root length } \\
(\text { in } \mathrm{cm})\end{array}$ & $5 \pm 4.5$ & $5 \pm 3.5$ & $5 \pm 4.2$ & $7 \pm 1.2$ & $4 \pm 1.5$ & $5 \pm 3.5$ & $4 \pm 4.5$ & $5 \pm 4.2$ & $6 \pm 4.5$ & $4 \pm 3.5$ \\
\hline $\begin{array}{ll}\text { Root } & \text { fresh } \\
\text { weight } & \\
\text { (mg\plant) } & \\
\end{array}$ & $8 \pm 8.5$ & $7 \pm 4.5$ & $8 \pm 2.3$ & $9 \pm 9.5$ & $5 \pm 1.5$ & $6 \pm 4.9$ & $6 \pm 1.3$ & $7 \pm 1.5$ & $9 \pm 1.5$ & $5 \pm 4.9$ \\
\hline $\begin{array}{l}\text { Root dry weight } \\
\text { (mg\plant) }\end{array}$ & $7 \pm 2.5$ & $6 \pm 5.4$ & $7 \pm 1.2$ & $7 \pm 4.2$ & $5 \pm 2.2$ & $6 \pm 3.2$ & $6 \pm 2.1$ & $6 \pm 4.1$ & $7 \pm 3.8$ & $5 \pm 3.5$ \\
\hline
\end{tabular}


International Journal of Trend in Scientific Research and Development (IJTSRD) ISSN: 2456-6470

Table :6 Effect of liquid biofertilizer on morphological parameters of VignaradiataL. $\left(45^{\text {th }}\right.$ day)

\begin{tabular}{|c|c|c|c|c|c|c|c|c|c|c|}
\hline \multirow{2}{*}{$\begin{array}{l}\text { Morphological } \\
\text { Parameters }\end{array}$} & \multicolumn{10}{|c|}{ Treatments } \\
\hline & T1 & T2 & T3 & $\mathbf{T 4}$ & T5 & T6 & T7 & T8 & T9 & T10 \\
\hline $\begin{array}{l}\text { Height of the } \\
\text { plant (in cm) }\end{array}$ & $12 \pm 5.1$ & $11 \pm 2.2$ & $11 \pm 0.5$ & $16 \pm 2.4$ & $8 \pm 2.7$ & $9 \pm 4.5$ & $9 \pm 3.5$ & $10 \pm 2.1$ & $15 \pm 2.6$ & $8 \pm 8.2$ \\
\hline $\begin{array}{l}\text { Inter nodal } \\
\text { length (in cm) }\end{array}$ & $6 \pm 4.2$ & $5 \pm 2.5$ & $6 \pm 2.9$ & $7 \pm 4.5$ & $4 \pm 2.9$ & $5 \pm 3.7$ & $4 \pm 3.6$ & $5 \pm 8.4$ & $6 \pm 5.8$ & $4 \pm 9.5$ \\
\hline $\begin{array}{l}\text { Number of } \\
\text { leaves } \\
\text { (per plant) }\end{array}$ & $11 \pm 2.3$ & $10 \pm 4.9$ & $11 \pm 1.5$ & $12 \pm 2.3$ & $8 \pm 4.9$ & $9 \pm 5.2$ & $9 \pm 3.5$ & $10 \pm 2.5$ & $11 \pm 4.9$ & $8 \pm 2.8$ \\
\hline $\begin{array}{l}\text { Leaf fresh } \\
\text { weight } \\
\text { (mg\plant) }\end{array}$ & $11 \pm 3.9$ & $11 \pm 1.2$ & & $12 \pm 2.5$ & $7 \pm 1.5$ & $9 \pm 2$ & $9 \pm 1.5$ & $10 \pm 9.2$ & $12 \pm 1.2$ & $7 \pm 5.5$ \\
\hline $\begin{array}{l}\text { Leaf dry } \\
\text { weight } \\
\text { (mg\plant) }\end{array}$ & $8 \pm 3.8$ & & & $9 \pm 5.6$ & $5 \pm 2.5$ & $6 \pm 7.2$ & & $7 \pm 5.6$ & $9 \pm 4.9$ & $5 \pm 5.9$ \\
\hline $\begin{array}{l}\text { Number of } \\
\text { root nodules } \\
\text { (per plant) }\end{array}$ & $7 \pm 4$ & $6 \pm$ & $7 \pm 2$ & $8 \pm 6.7$ & $5 \pm 1.5$ & $6 \pm 2.4$ & $6 \pm 0.6$ & $6 \pm 8.8$ & $8 \pm 5.9$ & $5 \pm 4.2$ \\
\hline $\begin{array}{l}\text { Shoot length } \\
\text { (in } \mathrm{cm} \text { ) }\end{array}$ & $7 \pm 3.2$ & $6 \pm 2.5$ & & $\begin{array}{l}8 \pm 1.2 \\
\text { and in }\end{array}$ & $\begin{array}{r}3 \pm 6.8 \\
\mathrm{Sci}\end{array}$ & $\begin{array}{l}4 \pm 8.5 \\
\text { ntific }\end{array}$ & $4 \pm 4.5$ & $5 \pm 0.2$ & $7 \pm 8.2$ & $3 \pm 8.2$ \\
\hline $\begin{array}{l}\text { Root length } \\
\text { (in cm) }\end{array}$ & $6 \pm 4$ & $6 \pm 0.8$ & $6 \pm$ & $8 \pm 5.7$ & $4 \pm 4.3$ & $5 \pm 6.8$ & $5 \pm 5.5$ & $5 \pm 7.5$ & $8 \pm 4.5$ & $4 \pm 5.3$ \\
\hline $\begin{array}{l}\text { Root fresh } \\
\text { weight } \\
\text { (mg\plant) }\end{array}$ & $10 \pm 2.5$ & $9 \pm 2.3$ & $9 \pm 4.5$ & $10 \pm 5.6$ & $\begin{array}{l}6 \pm 4.2 \\
56=64\end{array}$ & $8 \pm 2.6$ & $7 \pm 4.9$ & $8 \pm 4.5$ & $10 \pm 4.5$ & $7 \pm 3.1$ \\
\hline $\begin{array}{ll}\text { Root } & \text { dry } \\
\text { weight } & \\
\text { (mg\plant) } & \\
\end{array}$ & $9 \pm 1.5$ & $8 \pm 1$ & $8 \pm 2.6$ & $9 \pm 4.5$ & $6 \pm 3.1$ & $7 \pm 3.2$ & $7 \pm 1.5$ & $7 \pm 4.9$ & $9 \pm 3.2$ & $6 \pm 4.2$ \\
\hline $\begin{array}{l}\text { Number of } \\
\text { flowers } \\
\text { (per plant) }\end{array}$ & $12 \pm 1.5$ & $11 \pm 6.4$ & $11 \pm 7.5$ & $16 \pm 2.3$ & $7 \pm 7.3$ & $10 \pm 6.5$ & $10 \pm 4.7$ & $9 \pm 5.2$ & $15 \pm 2.7$ & $8 \pm 4.3$ \\
\hline
\end{tabular}

Table - 7 Effect of liquid biofertilizer on morphological parameters and yield of VignaradiataL. $\left(60^{\text {th }}\right.$ day $)$

\begin{tabular}{|l|c|c|c|c|c|c|c|c|c|c|}
\hline \multicolumn{1}{|c|}{\begin{tabular}{c} 
Morphological \\
\cline { 2 - 12 }
\end{tabular}} & $\mathbf{T 1}$ & $\mathbf{T 2}$ & $\mathbf{T 3}$ & $\mathbf{T 4}$ & $\mathbf{T 5}$ & $\mathbf{T 6}$ & $\mathbf{T 7}$ & $\mathbf{T 8}$ & $\mathbf{T 9}$ & $\mathbf{T 1 0}$ \\
\hline $\begin{array}{l}\text { Height of the } \\
\text { plant (in cm) }\end{array}$ & $23 \pm 2.9$ & $21 \pm 3.9$ & $22 \pm 4.1$ & $25 \pm 2.9$ & $16 \pm 8.2$ & $20 \pm 3.5$ & $19 \pm 5.1$ & $21 \pm 2.6$ & $24 \pm 8.7$ & $17 \pm 1.9$ \\
\hline $\begin{array}{l}\text { Inter nodal } \\
\text { length (in cm) }\end{array}$ & $9 \pm 4.3$ & $8 \pm 4.5$ & $7 \pm 2.5$ & $10 \pm 4.5$ & $6 \pm 1.5$ & $7 \pm 2.3$ & $7 \pm 1.5$ & $7 \pm 5.6$ & $10 \pm 1.5$ & $6 \pm 4.9$ \\
\hline $\begin{array}{l}\text { Number of } \\
\text { leaves (per } \\
\text { plant) }\end{array}$ & $19 \pm 2.8$ & $17 \pm 2.6$ & $18 \pm 2.9$ & $21 \pm 5.5$ & $9 \pm 9.8$ & $16 \pm 2.8$ & $16 \pm 2.5$ & $16 \pm 4.7$ & $20 \pm 8.7$ & $10 \pm 1.2$ \\
\hline
\end{tabular}


International Journal of Trend in Scientific Research and Development (IJTSRD) ISSN: 2456-6470

\begin{tabular}{|c|c|c|c|c|c|c|c|c|c|c|}
\hline $\begin{array}{l}\text { Leaf fresh } \\
\text { weight } \\
\text { (mg\plant) }\end{array}$ & $14 \pm 5.2$ & $14 \pm 3.2$ & $14 \pm 4.5$ & $15 \pm 4.5$ & $11 \pm 1.5$ & $13 \pm 5.6$ & $12 \pm 2.5$ & $14 \pm 2.3$ & $15 \pm 1.5$ & $11 \pm 3.2$ \\
\hline $\begin{array}{ll}\text { Leaf } & \text { dry } \\
\text { weight } \\
\text { (mg\plant) }\end{array}$ & $13 \pm 3.2$ & $12 \pm 4.5$ & $13 \pm 1.2$ & $13 \pm 5.2$ & $10 \pm 3.5$ & $11 \pm 4.9$ & $11 \pm 1.5$ & $12 \pm 3.5$ & $13 \pm 4.5$ & $10 \pm 4.2$ \\
\hline $\begin{array}{lr}\text { Number } & \text { of } \\
\text { pods } & \text { (per } \\
\text { plant) } & \end{array}$ & $12 \pm 1.5$ & $11 \pm 4.5$ & $11 \pm 6.5$ & $14 \pm 2.3$ & $8 \pm 2.2$ & $10 \pm 1.6$ & $9 \pm 4.6$ & $10 \pm 5.5$ & $13 \pm 2.5$ & $8 \pm 3.5$ \\
\hline $\begin{array}{l}\text { Number of } \\
\text { seeds } \\
\text { (per plant) }\end{array}$ & $16 \pm 4.6$ & $16 \pm 0.2$ & $16 \pm 1.5$ & $19 \pm 9.5$ & $12 \pm 0.9$ & $14 \pm 2.5$ & $13 \pm 2.8$ & $15 \pm 2.5$ & $17 \pm 8.9$ & $12 \pm 3.2$ \\
\hline $\begin{array}{l}\text { Number of root } \\
\text { nodules } \\
\text { (per plant) }\end{array}$ & $19 \pm 4.5$ & $18 \pm 4.2$ & $18 \pm 4.8$ & $20 \pm 8.5$ & $16 \pm 2.5$ & $17 \pm 4.5$ & $17 \pm 2.8$ & $17 \pm 5.6$ & $19 \pm 7.9$ & $16 \pm 4.6$ \\
\hline $\begin{array}{l}\text { Shoot length } \\
\text { (in cm) }\end{array}$ & $11 \pm 6.7$ & $10 \pm 1.5$ & $9 \pm 4.2$ & $13 \pm 4.1$ & $7 \pm 2.5$ & $8 \pm 4.5$ & $8 \pm 1.2$ & $9 \pm 2.5$ & $12 \pm 4.2$ & $7 \pm 4.5$ \\
\hline $\begin{array}{l}\text { Root length } \\
\text { (in cm) }\end{array}$ & $11 \pm 4.9$ & $11 \pm 1.2$ & $11 \pm 3.4$ & $12 \pm 4.5$ & $9 \pm 2.5$ & $10 \pm 3.9$ & $10 \pm 2.5$ & $10 \pm 4.6$ & $12 \pm 1.5$ & $9 \pm 4.5$ \\
\hline $\begin{array}{l}\text { Root fresh } \\
\text { weight } \\
\text { (mg\plant) }\end{array}$ & $12 \pm 4.5$ & $11 \pm 4.8$ & $12 \pm 2.5$ & $13 \pm 2.5$ & $8 \pm 3.5$ & $10 \pm 3.2$ & & $10 \pm 4.5$ & $13 \pm 0.2$ & $8 \pm 4.2$ \\
\hline $\begin{array}{ll}\text { Root } & \text { dry } \\
\text { weight } & \\
\text { (mg\plant) } & \\
\end{array}$ & $9 \pm 6.7$ & $9 \pm 1.5$ & $9 \pm 4.2$ & $10 \pm 2.5$ & $6 \pm 4.5$ & $8 \pm 4.5$ & $8 \pm 2.2$ & $8 \pm 5.6$ & $10 \pm 0.7$ & $7 \pm 2.1$ \\
\hline $\begin{array}{l}\text { Yield } \\
\text { (seed in gram) }\end{array}$ & $16 \pm 4.6$ & $16 \pm 0.2$ & $16 \pm 1.5$ & $19 \pm 9.5$ & $12 \pm 0.9$ & $14 \pm 2.5$ & $13 \pm 2.8$ & $15 \pm 2.5$ & $17 \pm 8.9$ & $12 \pm 3.2$ \\
\hline
\end{tabular}

Values are triplicates, mean \pm standard deviation

\section{RESULTS AND DISCUSSION}

The present study was carried out to isolate and identify the bacterial and fungal species from paddy field soils at Vedharaniyam, Nagappatinam District, Tamilnadu, South India. The effect of different liquid biofertilizer on growth and productivity of VignaradiataL. were studied. The results shown that viability of bacterium and fungi tend to decline during storage of biofertilizer but did not significantly reduce the effect on growth and production of plant. Generally, fungi and bacteria found in deep layer or slow growing due to unavailability of mineral nutrients and compaction of soil along depth (Dkhar and Mishra, 1992).

Physical features of liquid Rhizobiumspwasdull white in colour, No bad smell, No foam formation and $\mathrm{pH}$ 6.8 to 7.5 was observed. Colour of the liquid Azospirillumsp may be blue or dull white. Bad odours confirm improper liquid may be broth. Production of yellow gummy colour materials confirms the quality product. Acidic $\mathrm{pH}$ always confirms no Azospirillumspbacteria present in liquid (Pindi and Satyanarayana, 2012).

\section{Morphometric Parameters}

\section{Height of the Plant (in cm)}

At $30^{\text {th }}$ day, maximum height of the plant was recorded in T4 $(14 \pm 2.3)$ and T9 $(13 \pm 2.5)$ the combined inoculations, followed by other treatments, T1 (10 \pm 5.1$), \mathrm{T} 3(9.2 \pm 4.5), \mathrm{T} 2(9 \pm 3.3), \mathrm{T} 8(9 \pm 2.5), \mathrm{T} 6$

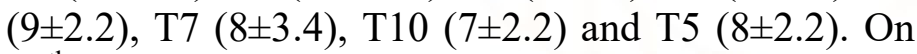
$45^{\text {th }}$ day, maximum height of the plant was observed in combined inoculation T4 (16 \pm 2.4$)$ and T9 (15 \pm 2.6$)$ followed by T1 $(12 \pm 5.1)$, T3 $(11 \pm 0.5)$, T2 $(11 \pm 2.2)$,

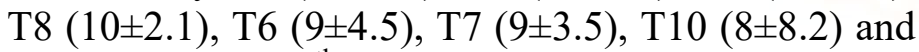
T5 (8 \pm 2.7$)$. On $60^{\text {th }}$ day, maximum height of the plant was shown by T4 (25 \pm 2.9$)$ and T9 (24 \pm 8.7$)(21 \pm 2.6)$ followed by T1 $(23 \pm 2.9), \mathrm{T} 3(22 \pm 4.1), \mathrm{T} 2(21 \pm 3.9)$,

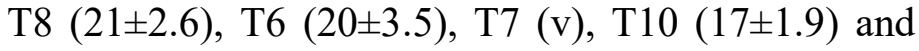
T5 (16 \pm 8.2$)$ (Plate - VII, Fig - 1 and Table -5 to 7 ). 


\section{Number of Leaves (per plant)}

At $30^{\text {th }}$ day, maximum number of leaves in the plant was recorded in T4 $(9 \pm 4.5)$ and T9 $(9 \pm 3.2)$ the combined inoculations, followed by T1 $(9 \pm 2.1)$, T3

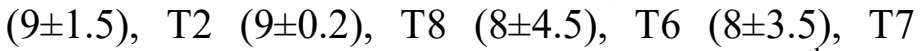
$(8 \pm 1.2)$, T10 $(7 \pm 2.3)$ and T5 $(7 \pm 1.2)$. On $45^{\text {th }}$ day, maximum number of leaves in the plant was observed in combined inoculation of $\mathrm{T} 4(12 \pm 2.3)$ and $\mathrm{T} 9$ $(11 \pm 4.9)$ followed by T1 $(11 \pm 2.3)$, T3 $(11 \pm 1.5)$, T2 $(10 \pm 4.9)$, T8 $(9 \pm 5.2), \mathrm{T} 6(9 \pm 3.5), \mathrm{T} 7(10 \pm 2.5), \mathrm{T} 10$ $(8 \pm 2.8)$ and T5 $(8 \pm 4.9)$. On $60^{\text {th }}$ day, maximum leaves in the plant was shown by $\mathrm{T} 4(21 \pm 5.5)$ and $\mathrm{T} 9$

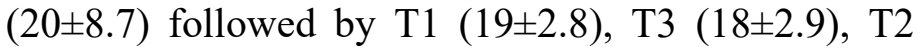
(17 \pm 2.6$)$, T8 (16 \pm 4.7$)$, T6 (16 \pm 2.8$),$ T7 (16 \pm 2.5$),$ T10 $(10 \pm 1.2)$ and $\mathrm{T} 5(9 \pm 9.8)($ Table -5 to 7$)$.

\section{Number of Flowers (per plant)}

On $45^{\text {th }}$ day maximum number of flowers in the plant was recorded in T4 $(16 \pm 2.3)$ and T9 $(15 \pm 2.7)$ followed by other liquid biofertilizer treatments $\mathrm{T} 1$ $(12 \pm 1.5), \mathrm{T} 3(11 \pm 7.5), \mathrm{T} 2(11 \pm 6.4), \mathrm{T} 8(9 \pm 5.2), \mathrm{T} 6$ $(10 \pm 6.5), \mathrm{T} 7(10 \pm 4.7), \mathrm{T} 10(8 \pm 4.3)$ and $\mathrm{T} 5(7 \pm 7.3)$ (Table - 6).

\section{Number of Root Nodules (per plant)}

Among the overall treatments on $30^{\text {th }}$ day, maximum number of root nodules were recorded in combined inoculation such as, $\mathrm{T} 4(7 \pm 6.5)$ and $\mathrm{T} 9(7 \pm 5.7)$ followed by T1 $(6 \pm 4.5)$, T3 (5 52.8$), \mathrm{T} 2(5 \pm 2.6)$, T8 (5 \pm 2.6$),$ T6 (5 \pm 2.5$), \mathrm{T} 7(4 \pm 2.5), \mathrm{T} 10(4 \pm 2.2)$ and T5 $(4 \pm 1.2)$. Among the overall treatments on $45^{\text {th }}$ day, maximum number of root nodules were recorded in combined inoculation such as T4 $(8 \pm 6.7)$ and T9

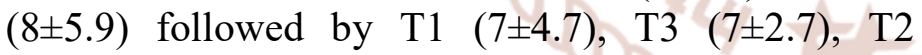
$(6 \pm 8.9), \mathrm{T} 8(6 \pm 8.8), \mathrm{T} 6(6 \pm 2.4), \mathrm{T} 7(6 \pm 0.6), \mathrm{T} 10$ $(5 \pm 4.2)$ and T5 $(5 \pm 1.5)$. At $60^{\text {th }}$ day, maximum number of root nodules were recorded in combined inoculation such as T4 $(20 \pm 8.5)$ and T9 (19 \pm 7.9$)$

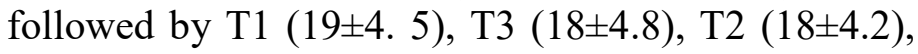
T8 (17 \pm 5.6$),$ T6 (17 \pm 4.5$),$ T7 $(17 \pm 2.8)$, T10 (16 \pm 4.6$)$ and T5 (16 \pm 2.5$)$ (Table -5 to 7$)$.

\section{Shoot Length (in cm)}

On $30^{\text {th }}$ day, maximum number of shoot length in the plant was observed in combined inoculation of $\mathrm{T} 4$

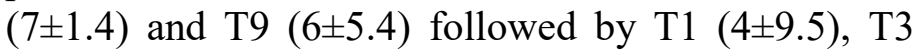

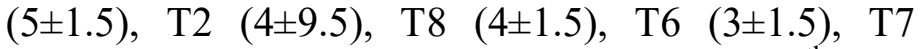
$(4 \pm 4.2), \mathrm{T} 10(3 \pm 3.8)$ and $\mathrm{T} 5(7 \pm 2.1)$. At $45^{\text {th }}$ day, maximum number of shoot length was recorded in combined inoculation such as T4 $(8 \pm 1.2)$ and $\mathrm{T} 9$ (3 38.2$)$ followed by $\mathrm{T} 1 \quad(7 \pm 3.2)$, T3 $(5 \pm 2.8)$, T2

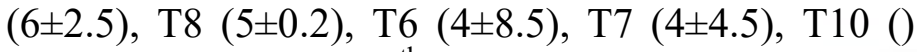

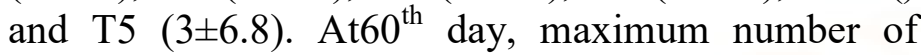
shoot length was recorded in combined inoculation such as, T4 (13 \pm 4.1$)$ and T9 $(12 \pm 4.2)$ followed by T1 $(11 \pm 6.7), \mathrm{T} 3(9 \pm 4.2), \mathrm{T} 2(10 \pm 1.5), \mathrm{T} 8(8 \pm 1.2)$, T6 $(8 \pm 4.5), \mathrm{T} 7(8 \pm 1.2), \mathrm{T} 10(7 \pm 4.5)$ and $\mathrm{T} 5(7 \pm 2.5)$ (Table -5 to 7 ).

\section{Root Length (in cm)}

On $30^{\text {th }}$ day, maximum number of root length in the plant was observed in combined inoculation of $\mathrm{T} 4$ $(7 \pm 1.2)$ and T9 $(6 \pm 4.5)$ followed by T1 $(5 \pm 4.5)$, T3 $(5 \pm 4.2), \quad \mathrm{T} 2 \quad(5 \pm 3.5), \quad \mathrm{T} 8(5 \pm 4.2), \mathrm{T} 6 \quad(5 \pm 3.5), \mathrm{T} 7$

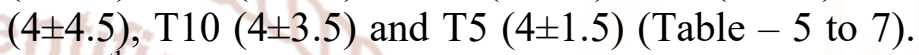
At $45^{\text {th }}$ day, maximum number of root length in the plant was observed in combined inoculation of $\mathrm{T} 4$ $(8 \pm 5.7)$ and T9 $(8 \pm 4.5)$ followed by T1 $(6 \pm 4.2)$, T3 $(6 \pm 1.5), \quad \mathrm{T} 2 \quad(6 \pm 0.8), \quad \mathrm{T} 8 \quad(5 \pm 7.5), \quad \mathrm{T} 6 \quad(5 \pm 6.8), \mathrm{T} 7$ $(5 \pm 5.5), \mathrm{T} 10(4 \pm 5.3)$ and $\mathrm{T} 5(4 \pm 4.3)$. AtIn $60^{\text {th }}$ day, maximum number of root length in the plant was observed in combined inoculation of T4 (12 \pm 4.5$)$ and T9 (12 \pm 1.5$)$ followed by T1 $(11 \pm 4.9)$, T3 $(11 \pm 3.4)$,

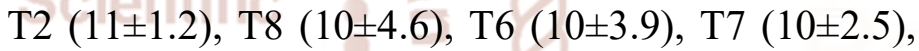
$\mathrm{T} 10(9 \pm 4.5)$ and T5 $(9 \pm 2.5)$.

\section{Internodal Length (in cm)}

At $30^{\text {th }}$ day, maximum level of inter nodule length was recorded in combined inoculations, i.e., T4 $(5 \pm 4.2)$ and T9 $(5 \pm 2.5)$ followed by T1 $(4 \pm 5.1)$, T3

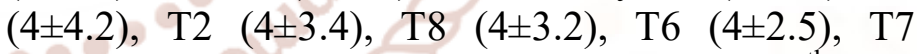
(3 \pm 9.2$), \mathrm{T} 10(3 \pm 2.3)$ and T5 $(3 \pm 2.1)$. On $45^{\text {th }}$ day, maximum level of inter nodule length was recorded in combined inoculations, T4 $(7 \pm 4.5)$ and $\mathrm{T} 9(6 \pm 5.8)$ followed by $\mathrm{T} 1(6 \pm 4.2), \mathrm{T} 3(6 \pm 2.9), \mathrm{T} 2(5 \pm 2.5), \mathrm{T} 8$ $(5 \pm 8.4), \mathrm{T} 6(5 \pm 3.7), \mathrm{T} 7(4 \pm 3.6), \mathrm{T} 10(4 \pm 9.5)$ and $\mathrm{T} 5$ (4 \pm 2.9$)$. At $60^{\text {th }}$ day, maximum level of inter nodule length was recorded in combined inoculations, T4 $(10 \pm 4.5)$ and $\mathrm{T} 9(10 \pm 1.5)$ followed by $\mathrm{T} 1(9 \pm 4.3)$, T3

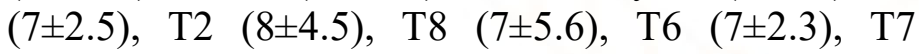

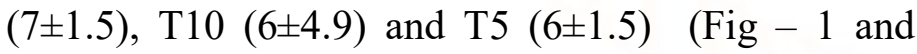
Table -5 to 7$)$.

\section{Leaf Fresh Weight (mg\pant)}

At $30^{\text {th }}$ day, maximum level of leaf fresh weight was

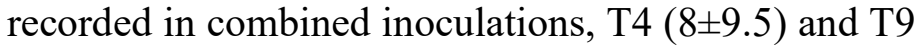
$(8 \pm 8.2)$ followed by other treatments, $\mathrm{T} 1(8 \pm 7.5), \mathrm{T} 3$ $(8 \pm 6.8)$, T2 $(8 \pm 5.7)$, T8 $(7 \pm 5.9)$, T6 $(7 \pm 2.5)$, T7 $(7 \pm 1.2), \mathrm{T} 10(6 \pm 5.2)$ and T5 $(6 \pm 2.5)$. At $45^{\text {th }}$ day, 
maximum level of leaf fresh weight was recorded in T4 (12 \pm 2.5$)$ and T9 $(12 \pm 1.2)$ the combined inoculations, followed by $\mathrm{T} 1(11 \pm 3.9), \mathrm{T} 3(11 \pm 2.2)$,

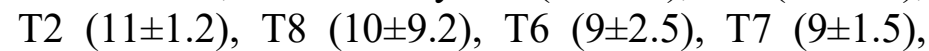

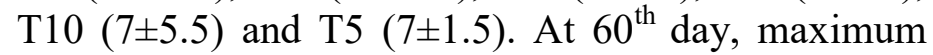
level of leaf fresh weight was observed in combined inoculation of T4 $(15 \pm 4.5)$ and $\mathrm{T} 9(15 \pm 1.5)$ followed by T1 $(14 \pm 5.2)$, T3 $(14 \pm 4.5), \quad$ T2 $(14 \pm 3.2), \quad$ T8 $(14 \pm 2.3), \mathrm{T} 6(13 \pm 5.6), \mathrm{T} 7(12 \pm 2.5), \mathrm{T} 10(11 \pm 3.2)$ and T5 (11 \pm 1.5$)($ Table -5 to 7 and Fig -3$)$.

\section{Leaf Dry Weight (mg $\backslash$ plant)}

At $30^{\text {th }}$ day, maximum level of leaf dry weight was observed in combined inoculation of T4 $(6 \pm 8.5)$ and T9 (6 $6 \pm 7.2)$ followed by other treatments $\mathrm{T} 1(6 \pm 6.5)$,

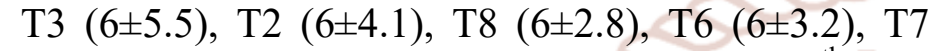
$(6 \pm 1.5), \mathrm{T} 10(5 \pm 4.9)$ and T5 $(5 \pm 1.5)$. On $45^{\text {th }}$ day, maximum level of leaf dry weight was shown by combined inoculation of T4 $(9 \pm 5.6)$ and T9 $(9 \pm 4.9)$ followed by other treatments, T1 $(8 \pm 3.8)$, T3 $(8 \pm 2.5)$,

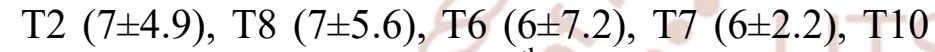
$(5 \pm 5.9)$ and $\mathrm{T} 5(5 \pm 2.5)$. In $60^{\text {th }}$ day maximum level of leaf dry weight was shown by combined inoculation of T4 $(13 \pm 5.2)$ and T9 $(13 \pm 4.5)$ followed by T1 (13 \pm 3.2$),$ T3 $(13 \pm 1.2)$, T2 (12 \pm 4.5$),$ T8 $(12 \pm 3.5)$, T6 (11 \pm 4.9$),$ T7 $(11 \pm 1.5), \mathrm{T} 10(10 \pm 4.2)$ and T5 $(10 \pm 3.5)$ (Table -5 to 7 and Fig -3 ).

\section{Root Fresh Weight (mg $\backslash$ plant)}

At $30^{\text {th }}$ maximum level of root fresh weight was observed in combined inoculation of $\mathrm{T} 4(9 \pm 9.5)$ and

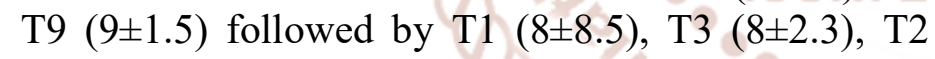

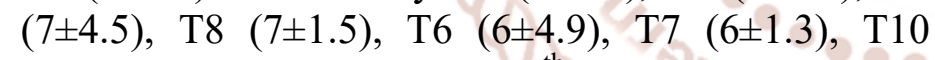
$(5 \pm 4.9)$ and $\mathrm{T} 5(5 \pm 1.5)$. On $45^{\text {th }}$ day, maximum level of root fresh weight was shown by combined inoculation of T4 $(10 \pm 5.6)$ and $\mathrm{T} 9(10 \pm 4.5)$ followed by T1 $(10 \pm 2.5), \mathrm{T} 3(9 \pm 4.5), \mathrm{T} 2(9 \pm 2.3), \mathrm{T} 8(8 \pm 4.5)$,

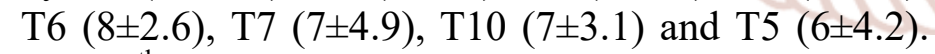
On $60^{\text {th }}$ day, maximum of root fresh weight was recorded in combined inoculation of T4 $(10 \pm 2.5)$ and T9 (10 \pm 0.7$)$ followed by other treatments T1 $(9 \pm 6.7)$,

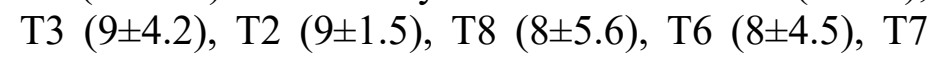
$(8 \pm 2.2), \mathrm{T} 10(7 \pm 2.1)$ and T5 $(6 \pm 4.5)$ (Fig -5 and Table -5 to 7 ).

\section{Root Dry Weight (mg $\backslash$ plant)}

At $30^{\text {th }}$ day, maximum level of root dry weight was observed in T4 $(7 \pm 4.2)$ and T9 $(7 \pm 3.8)$ followed by other treatments $\mathrm{T} 1(7 \pm 2.5), \mathrm{T} 3(7 \pm 1.2), \mathrm{T} 2(6 \pm 5.4)$,

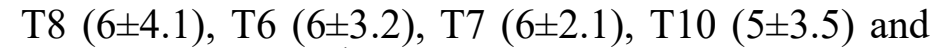
$\mathrm{T} 5$ (5 \pm 2.2$)$. At $45^{\text {th }}$ day, maximum level of root dry weight was observed in T4 $(9 \pm 4.5)$ and $\mathrm{T} 9(9 \pm 3.2)$ followed by other treatments T1 $(9 \pm 1.5), \mathrm{T} 3(8 \pm 2.6)$,

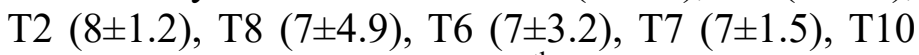
$(6 \pm 4.2)$ and T5 $(6 \pm 3.1)$. At $60^{\text {th }}$ day, maximum level of root dry weight was observed in T4 $(10 \pm 2.5)$ and T9 $(10 \pm 0.7)$ the combined inoculations, followed by other treatments $\mathrm{T} 1(9 \pm 6.7), \mathrm{T} 3(9 \pm 4.2), \mathrm{T} 2(9 \pm 1.5)$, T8 (8 \pm 5.6$),$ T6 $(8 \pm 4.5), \mathrm{T} 7(8 \pm 2.2), \mathrm{T} 10(7 \pm 2.1)$ and T5 (6 \pm 4.5$)$ (Fig -5 and Table- 1 to 7$)$.

\section{Number of Seeds (gm.|plant)}

On $60^{\text {th }}$ day, maximum level of seeds were observed

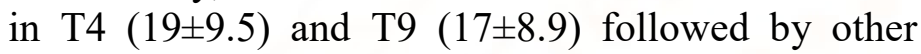
treatments T1 $(16 \pm 4.6), \mathrm{T} 3(16 \pm 1.5), \mathrm{T} 2(16 \pm 0.2), \mathrm{T} 8$ $(15 \pm 2.5)$, T6 (14 \pm 2.5$), \mathrm{T} 7(13 \pm 2.8), \mathrm{T} 10(12 \pm 3.2)$ and T5 (12 \pm 0.9$)$.

\section{Number of Pods (per plant)}

In $60^{\text {th }}$ day, maximum level of pods were observed in T4 (14 \pm 2.3$)$ and T9 $(13 \pm 2.5)$ the combined inoculations, followed by other treatments $\mathrm{T} 1$ $(12 \pm 1.5), \mathrm{T} 3(11 \pm 6.5), \mathrm{T} 2(11 \pm 4.5), \mathrm{T} 8(10 \pm 5.5), \mathrm{T} 6$

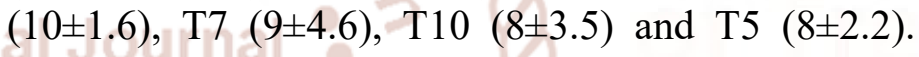
(Plate - IX and Table -7)

\section{Yield (seed in gram)}

In $60^{\text {th }}$ day, maximum level of yield was observed in combined inoculation of treatments such as, T4 (19 \pm 9.5) and T9 ( $17 \pm 8.9)$ followed by other treatments T1 (16 \pm 4.6$)$, T3 $(16 \pm 1.5)$, T2 $(16 \pm 1.2)$, T8 (15 \pm $5.8), \mathrm{T} 6(15 \pm 2.5), \mathrm{T} 7(13 \pm 2.8), \mathrm{T} 10(12 \pm 3.2)$ and T5 $(12 \pm 0.9)$.

\section{CONCLUSION}

Bacterial and fungal biofertilizers are presently used on a very small scale as compared to chemical compounds. There has been little investment in the research and development of bacterial and fungal products because these may have poor effect in the field. Future research therefore must develop bacterial and fungal products, which have significant effect in field applications and are stable under storage.

\section{REFERENCE}

1. Anita chanda, K. and Tanya, C. 2016. Production of liquid biofertilizer and study it's effectively on plant growth. International Journal of Agricutural science and Research, 6(3):211220(2016). 
2. Ansari, M.F.,Devayani, R., Tipre.andShailesh, R. Dave. Efficiency evalution of commercial liquid biofertilizers for growth of ciceraeritinum. $J$. Environs. Biol., 4(1): 17-24(2014).

3. Arcand, M.M. and Schneider, K.D. Plant and microbial-based mechanisms to improve the agronomic effectiveness of phosphate rock: a review. Ann. Acad. Bras. Ciênc. 78: 791807(2006).

4. Bailey, R.W. and Scott, B.G. Diagnostic Microbiology. $\quad 2^{\text {nd }}$ ed. St. Louis: C.V Microorganisms by company(1996).

5. Beijerinck,Bergey's Manual of Systematic Bacteriology. 8th ed., Baltimore: Williams and Wilkins Co., in press(1889).

6. Dkhar, M.S. and Mishra, R.R.. Microbial population of three different agricultural field soils of Meghalaya, Geobios new reports. 11: 6672(1992).

7. Dwivedi, R.S.. Soil fungi of grasslands of Varanasi I.Edaphic factors and fungi.Proc. Nat.Acad. Sci., 35:255-274(1966).

8. Ellis, M. B.. Dematiaceoushyphomycetes. Commonwealth Mycological Institute: kew, survey, UK(1971).
9. Han's Christain Gram, cellular response of bacteria to the Gram Stain. Journal of Bacteriology, 56(2) : 846-856(2006).

10. Harman, G.E. and Howell, C.R. Trichoderma species - opportunistic. A virulent plant sympionts. Nat. Rev .Microbial., 2: 43 -56(1884).

11. Norris, J.R. and Ribbons, D.W. Methods in Microbiology, Academic press New york. 4: 795 -799 (1972).

12. Pindi, P.K. and Satyanarayana, S.D.Liquid Microbial Consortium- A Potential Tool for Sustainable Soil Health. Journal of BiofertilBiopesticides., 3:4-6(2010).

13. Ronald Atlas, M.Serial Dilution technique. Fundamentals and Application ofMicrobial Ecology, 4: 694(1998).

14. Vinale, F., Sivasithamparam, K., Ghisalberti, E.L., Marra, R., Woo, S.L. and Lorito, M. Major secondary metabolites produced by two commercial Trichoermastrains active against different phytopathogens. Letters in Applied Microbiology, 43:143-148(2006).

15. Warcup, J.H. The soil plate methods for fungi from soil. Nature, $1: 117-118(1950)$. 